\title{
Effect of Oxygen Content on Microstructure and Tensile Properties of a 22Cr-5Al ODS Steel
}

\author{
Yukun Zhang ${ }^{1,2}$, Yingjie Yan ${ }^{1,2, *}$, Yazhong Zhai ${ }^{1,2}$, Wei Qin ${ }^{3}$, Hongyan Che ${ }^{3}$, Tiejun Wang ${ }^{3}$ and Rui Cao ${ }^{1,2}$ (D) \\ 1 State Key Laboratory of Advanced Processing and Recycling of Nonferrous Metals, Lanzhou University of \\ Technology, Langongping 287 Road, Qilihe District, Lanzhou 730050, China; zyklut@163.com (Y.Z.); \\ zhaiyazhong1995@163.com (Y.Z.); caorui@lut.edu.cn (R.C.) \\ 2 School of Materials Science and Engineering, Lanzhou University of Technology, Lanzhou 730050, China \\ 3 Advanced Technology \& Materials Limited Company, China Iron \& Steel Research Institute Group, \\ Beijing 100081, China; qinwei@atmcn.com (W.Q.); chehongyan@atmcn.com (H.C.); wangtj@atmcn.com (T.W.) \\ * Correspondence: yjyan@lut.edu.cn
}

Citation: Zhang, Y.; Yan, Y.; Zhai, Y.; Qin, W.; Che, H.; Wang, T.; Cao, R. Effect of Oxygen Content on Microstructure and Tensile Properties of a 22Cr-5Al ODS Steel. Materials 2021, 14, 2241. https://doi.org/ 10.3390/ma14092241

Academic Editor: Adam Grajcar

Received: 5 April 2021

Accepted: 22 April 2021

Published: 27 April 2021

Publisher's Note: MDPI stays neutral with regard to jurisdictional claims in published maps and institutional affiliations.

Copyright: (c) 2021 by the authors. Licensee MDPI, Basel, Switzerland. This article is an open access article distributed under the terms and conditions of the Creative Commons Attribution (CC BY) license (https:// creativecommons.org/licenses/by/ $4.0 /)$.

\begin{abstract}
The high tensile strength and irradiation resistance of oxide dispersion strengthened (ODS) ferritic steels is attributed to the ultrafine and dispersed oxides within the matrix. The high content of oxygen and yttrium is critical for the formation of dense Y-rich oxides. However, only few studies have reported the effect of oxygen content on the microstructure and mechanical properties of ODS steels. Herein, we employed gas atomization reactive synthesis to prepare pre-alloy powders and then hot isostatic pressing (HIP) to consolidate two 22Cr-5Al ODS steels with different oxygen content. Our results showed Y-rich precipitates at and near grain boundaries of the as-HIPed alloys. Moreover, with the oxygen content increasing from 0.04 to $0.16 \mathrm{wt} \%$, more precipitates precipitated in the as-HIPed alloy, and the ultimate tensile strength of the alloy was improved. However, increasing the oxygen content to $0.16 \mathrm{wt} \%$ led to formation of stripe and chain precipitates at and near grain boundaries, which caused a partial intergranular fracture of the as-HIPed alloy.
\end{abstract}

Keywords: 22Cr-5Al ODS steel; oxygen content; Y-rich precipitates; tensile properties

\section{Introduction}

Oxide dispersion strengthened (ODS) steels are key candidate structural materials for advanced nuclear systems [1-4]. The high density of nanoscale oxides provides ODS steels with excellent mechanical performance by blocking dislocation slipping and hindering grain boundaries movement [5-9]. Several studies have reported that fine and thermostable oxides improve the creep resistance of ferritic steels [10-13] and trap He in fine bubbles, thereby limiting He movement and restraining He brittleness [2-4]. The common processes to fabricate ODS steels are powder metallurgy (PM) with mechanical alloying (MA) and heat consolidation [14], including hot isostatic pressure (HIP) [9], hot extrusion (HE) $[15,16]$, and spark plasma sintering (SPS) [17], and ODS steels have a high density and an excellent tensile strength. In contrast to HIP and HE, laser additive manufacturing (LAM) $[18,19]$ without the MA process is a method used to manufacture the ODS Fe-matrix alloys because of its low cost and flexibility [18]. Yingnan Shi et al. fabricated a Zrcontaining ODS-FeCrAl alloy by LAM, which presented anisotropic tensile properties [18].

The excellent performance of ODS steels can be attributed to the rational composition design and introduction of ultrafine nano-oxides [20,21]. Previous studies have shown that micro-alloyed elements can react with $\mathrm{Y}$ and $\mathrm{O}$ to form $\mathrm{Y}$-containing oxides [22-25]. Surprisingly, the addition of $\mathrm{Al}$, which was expected to improve oxidation resistance of steels, deteriorated the high-temperature strength of the Al-containing ODS steel due to the coarsening tendency of Y-Al-O oxides at high temperatures [26,27]. An appropriate addition of $\mathrm{Zr}$ could effectively inhibit the coarsening of Al-containing oxides by forming more stable $\mathrm{Y}-\mathrm{Zr}-\mathrm{O}$ oxides in the matrix. The addition of $\mathrm{Ti}[28,29]$ can refine grains and 
form ternary oxides (Y-Ti-O), of smaller size and higher thermal stability than $\mathrm{Y}_{2} \mathrm{O}_{3}$, by reacting with $\mathrm{Y}$ and $\mathrm{O}$. Improving the $\mathrm{Ti} / \mathrm{Y}$ ratio can minimize the interfacial energy between particle and matrix, which reduces the coarsening rate of oxides at high temperatures [30]. The high oxygen is the main reason for the formation of powder boundaries (PPBs) in Ni-based super alloys fabricated through PM [31]. However, the high content of $\mathrm{Y}$ and $\mathrm{O}$ in ODS steel is necessary for the formation of fine and dense precipitates in the matrix to ensure its excellent comprehensive performance [32,33].

In this study, we prepared two Fe-22Cr-5Al ODS steels with different oxygen content in order to better understand the relationship among oxygen content, microstructure, and tensile strength. We characterized the microstructure and the precipitates of the alloys in detail, and we investigated the tensile properties and fracture behavior of the two steels at $25^{\circ} \mathrm{C}$. Finally, we discussed the relationship among oxygen, microstructure, and tensile strength according to the obtained results.

\section{Materials and Experiment}

We prepared Fe-22Cr-5Al-0.1Y powders with different oxygen content through Gas Atomization Reactive Synthesis (GARS) [34,35]. The powder size ranged from 50 to $350 \mu \mathrm{m}$. As shown in Figure 1a, the height of the powder can was $100 \mathrm{~mm}$, its inner diameter was $50 \mathrm{~mm}$, and the can wall thickness was $5 \mathrm{~mm}$. The vacuum within the can was $10^{-2}$ Pa before HIP. Subsequently, the powders were consolidated by HIP at $1220^{\circ} \mathrm{C}$ under a pressure of $150 \mathrm{MPa}$ for $3 \mathrm{~h}$ [34]. The obtained alloys were named as-HIPed alloy A (oxygen content: $0.04 \mathrm{wt} \%$ ) and B (oxygen content: $0.16 \mathrm{wt} \%$ ), and their chemical compositions are shown in Table 1 . The oxygen content of the alloys was tested by LECO TCH600 combined determination apparatus (LECO, Saint Joseph, MI, USA) for oxygen, nitrogen, and hydrogen.
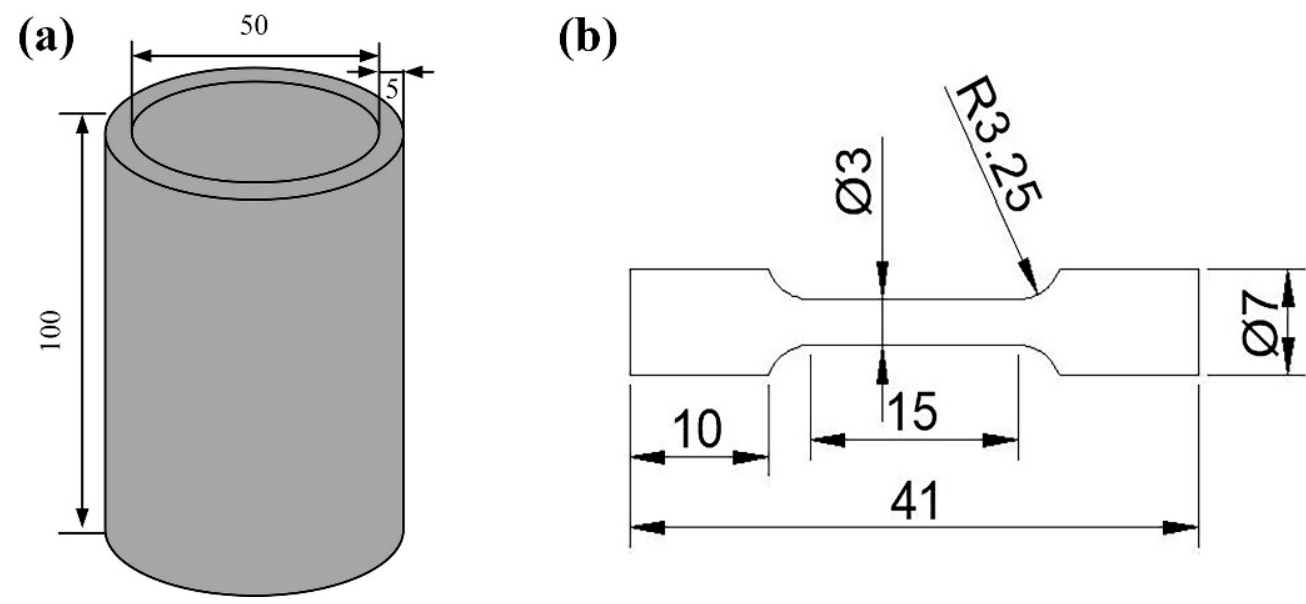

Figure 1. Schematic diagrams of (a) powder cans and (b) tensile samples (in mm).

Table 1. Chemical composition of the as-HIPed ODS steels (wt $\%$ ).

\begin{tabular}{cccccccc}
\hline & $\mathbf{O}$ & $\mathbf{C r}$ & $\mathbf{A l}$ & $\mathbf{T i}$ & $\mathbf{Y}$ & $\mathbf{Z r}$ & $\mathbf{F e}$ \\
\hline A & 0.04 & 22 & 5 & 0.11 & 0.11 & 0.1 & Bal. \\
B & 0.16 & 22 & 5 & 0.12 & 0.10 & 0.1 & Bal. \\
\hline
\end{tabular}

Next, the phase analysis of as-HIPed alloys was carried out by X-ray Diffraction (XRD) using a D/max-2400 X-ray diffractometer (Rigaku, Tokyo, Japan) with $\mathrm{Cu} \mathrm{K} \alpha$, and the scan rate was $10^{\circ} \cdot \mathrm{min}^{-1}$. We observed the microstructure of the as-HIPed samples using a Scanning Electron Microscope (SEM, Quanta 450FEG, FEI, Hillsboro, OR, USA) with an Energy Dispersion Spectrum (EDS) analyzer. Firstly, the samples used for SEM analysis were electro-etched in a 10\% perchloric acid alcohol solution at $23 \mathrm{~V}$ for $30 \mathrm{~s}$, followed 
by pickling in a $60 \%$ hydrochloric acid alcohol solution for $50 \mathrm{~s}$. We then conducted Transmission Electron Microscopy (TEM, JEM-2100F, JEOL, Tokyo, Japan) analysis using thin foil samples, which were mechanically thinned to $60 \mu \mathrm{m}$ and a diameter of $3 \mathrm{~mm}$. Next, the thin foils were electropolished using an MTA-1A twin jet polisher with a solution $(10 \%$ perchloric acid $+90 \%$ alcohol $)$ at $-30^{\circ} \mathrm{C}$. Finally, we carried out tensile tests at $25^{\circ} \mathrm{C}$ with a strain rate of $1 \mathrm{~mm} / \mathrm{min}$. As shown in Figure $1 \mathrm{~b}$, the samples with a gauge length of $15 \mathrm{~mm}$ and a gauge diameter of $3 \mathrm{~mm}$ were used for the tensile strength testing by the testing machine AGS-X300 (Shimadzu, Kyoto, Japan). Three tensile samples of each alloy were tested. Fractography and EDS on the fracture surfaces were analyzed by an SEM.

\section{Results}

\subsection{Microstructure}

Figure 2 shows the XRD profiles of the as-HIPed alloys A and B. It can be seen that the matrixes of the as-HIPed A and B mainly were in the $\alpha$-Fe phase due to the high $\mathrm{Cr}$ content [36]. Figure 3a,b shows an SEM secondary electron image of the macrostructure and the statistical distribution of grain sizes of the as-HIPed alloy A. The grain size of the alloy was calculated from the average lengths of the long and the short axes of the grains. According to the statistical analysis, the average and maximum grain sizes of the as-HIPed alloy A were $90 \mu \mathrm{m}$ and $318 \mu \mathrm{m}$, respectively (Figure 3b). Figure 3c shows the microstructures of the as-HIPed alloy A. Results indicated that the as-HIPed alloy A had spherical and dispersed precipitates (pointed by red arrows), most of which were distributed at grain boundaries (Figure 3c). According to the EDS results, the precipitates at grain boundaries were $\mathrm{Y}-, \mathrm{Zr}$ - and Ti-oxides (Figure $3 \mathrm{~d}$ ).

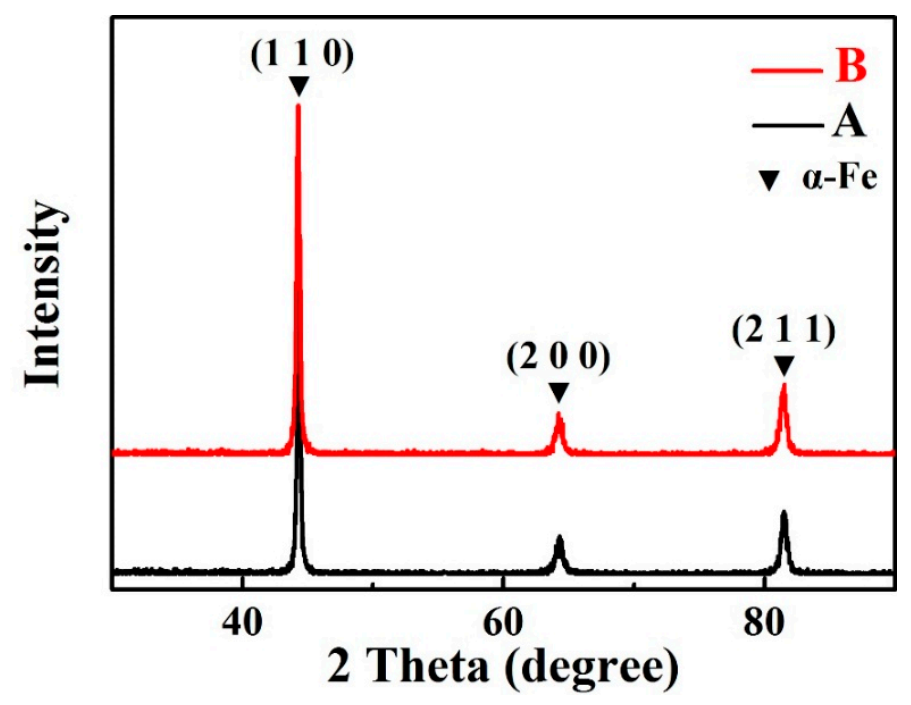

Figure 2. The XRD patterns of the as-HIPed alloys A and B. 

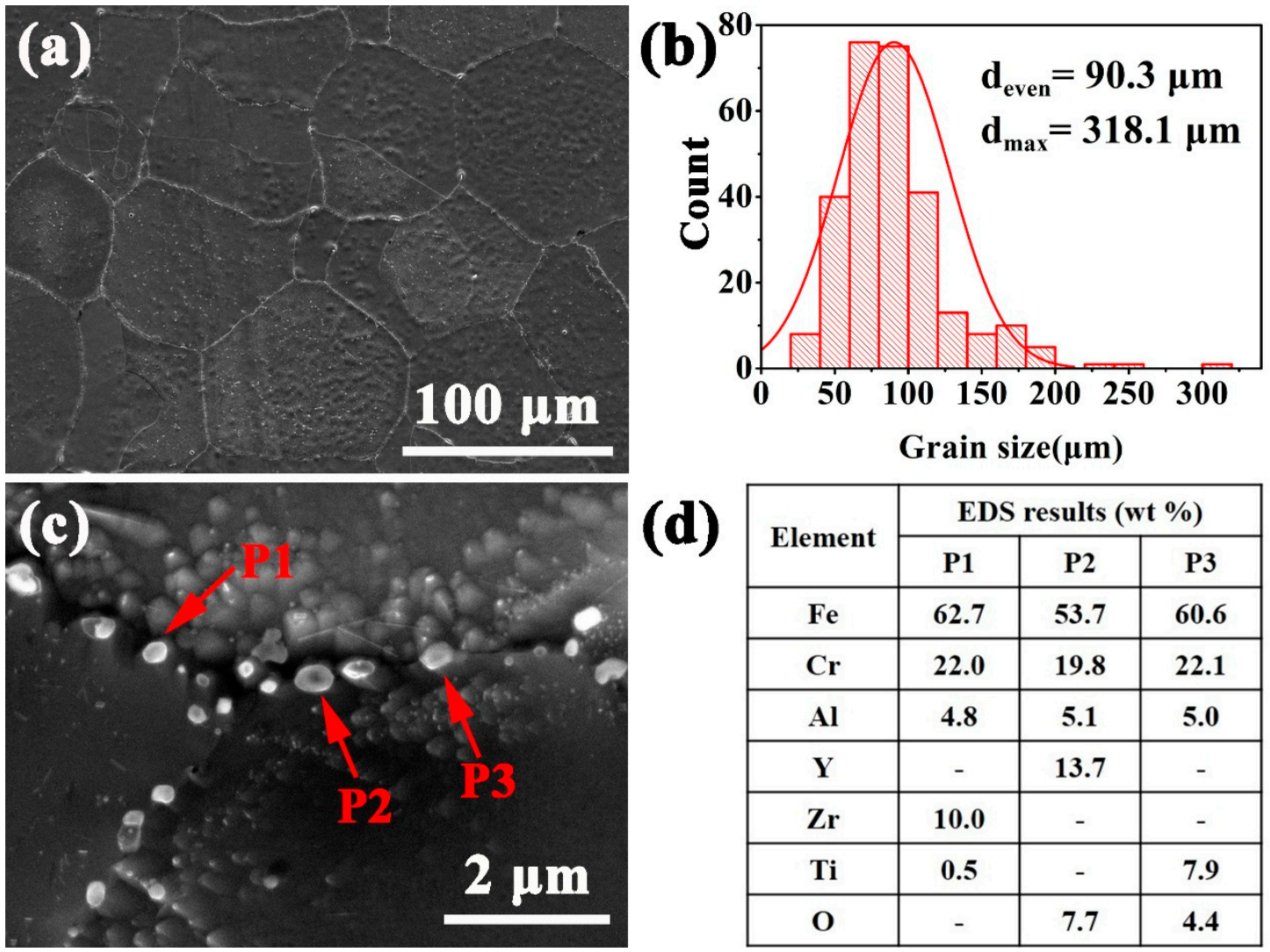

(d) \begin{tabular}{|c|c|c|c|}
\hline \multirow{2}{*}{ Element } & \multicolumn{3}{|c|}{ EDS results (wt \%) } \\
\cline { 2 - 5 } & $\mathrm{P} 1$ & $\mathrm{P} 2$ & $\mathrm{P3}$ \\
\hline $\mathrm{Fe}$ & 62.7 & 53.7 & 60.6 \\
\hline $\mathrm{Cr}$ & 22.0 & 19.8 & 22.1 \\
\hline $\mathrm{Al}$ & 4.8 & 5.1 & 5.0 \\
\hline $\mathrm{Y}$ & - & 13.7 & - \\
\hline $\mathrm{Zr}$ & 10.0 & - & - \\
\hline $\mathrm{Ti}$ & 0.5 & - & 7.9 \\
\hline $\mathrm{O}$ & - & 7.7 & 4.4 \\
\hline
\end{tabular}

Figure 3. Microstructure of the as-HIPed alloy A: (a) SEM secondary electron micrograph of the macrostructure; (b) distribution of grain sizes for the as-HIPed alloy A; (c) SEM secondary electron micrograph of precipitates at grain boundaries and (d) EDS results of the precipitates in (c).

Figure 4a,b shows an SEM secondary electron image of the macrostructure and the statistical distribution of grain sizes of the as-HIPed alloy B. The average and maximum grain sizes of the as-HIPed alloy B were $101 \mu \mathrm{m}$ and $297 \mu \mathrm{m}$, respectively (Figure $4 \mathrm{~b}$ ). Figure $4 \mathrm{c}, \mathrm{d}$ shows the microstructure of the as-HIPed alloy B and the EDS results of the precipitates pointed in Figure 4c. Results showed that in the as-HIPed alloy B, there were not only white spherical Y- and Ti-rich oxides at grain boundaries and within grains, but also stripe and chain precipitates at and near grain boundaries (highlighted by a red dashed line).

We also conducted TEM characterizations in order to systematically investigate the chain/stripe precipitates found in the as-HIPed alloy B. Figure 5 shows bright field images of precipitates in the as-HIPed alloy B. Results showed that there was a chain of precipitates with sizes ranging from 30 to $230 \mathrm{~nm}$ (marked by a red dashed line) close to the grain boundary (marked by black arrows) (Figure $5 a$ ). Figure 5 b shows a magnified image of the precipitates in Figure 5a marked by a blue dashed line. Moreover, the EDS results (Figure $5 \mathrm{~b}$ ) indicated that the spherical precipitates (diameter about $150 \mathrm{~nm}$, pointed by black arrows) had high $\mathrm{Y}$ and $\mathrm{O}$ content, while SAD (selective area diffraction) patterns confirmed that the precipitate (Figure $5 \mathrm{c}$ ) was cubic $\mathrm{Y}_{2} \mathrm{O}_{3}$ with a space group Ia-3 (206) with $\mathrm{a}=\mathrm{b}=\mathrm{c}=1.062 \mathrm{~nm}$ and $\alpha=\beta=\gamma=90^{\circ}$. 


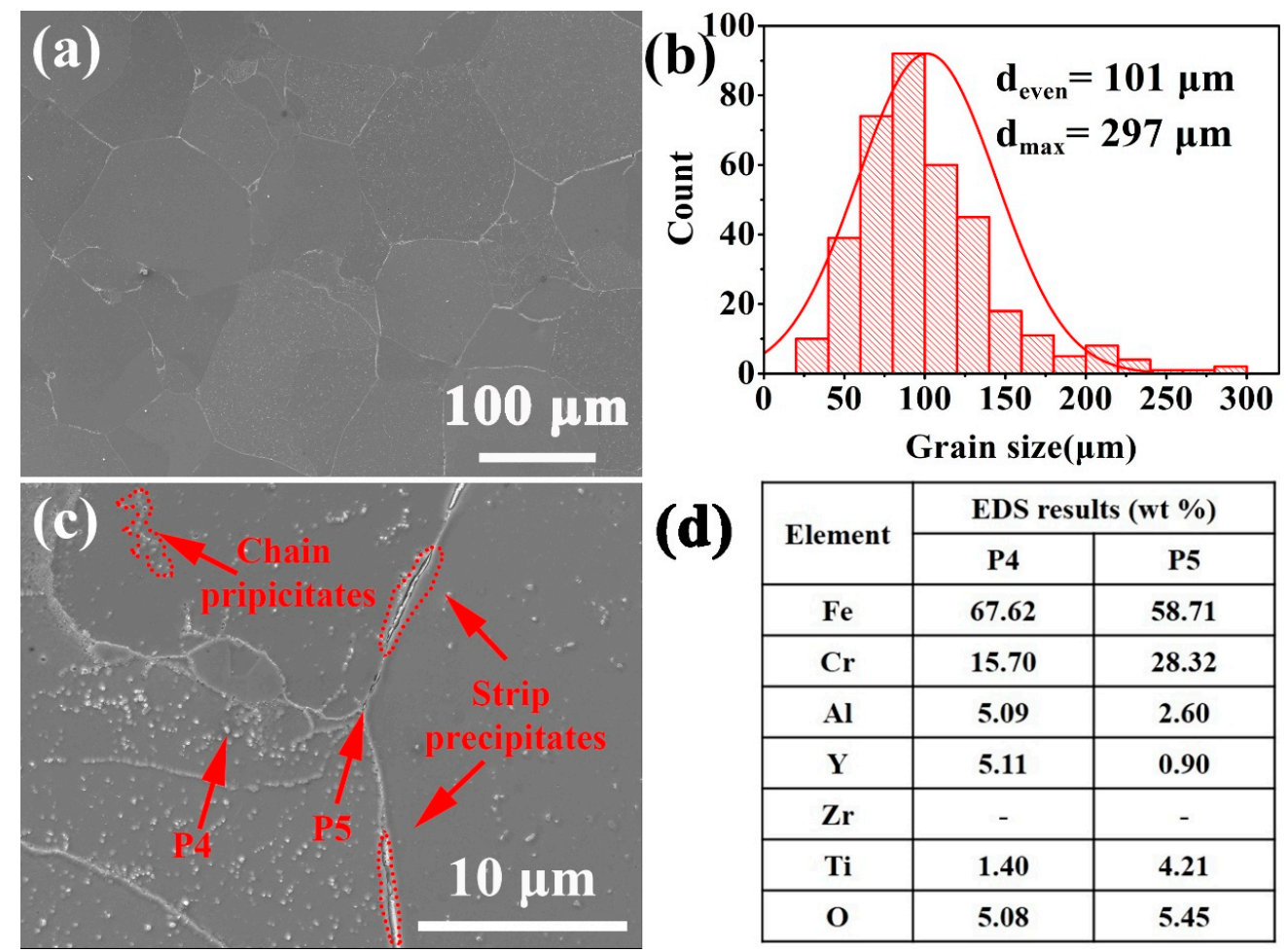

Figure 4. Microstructure of the as-HIPed alloy B: (a) SEM secondary electron micrograph of the macrostructure; (b) distribution of grain sizes for the as-HIPed alloy B; (c) SEM secondary electron micrograph of precipitates at grain boundaries and (d) EDS results of the precipitates in (c).
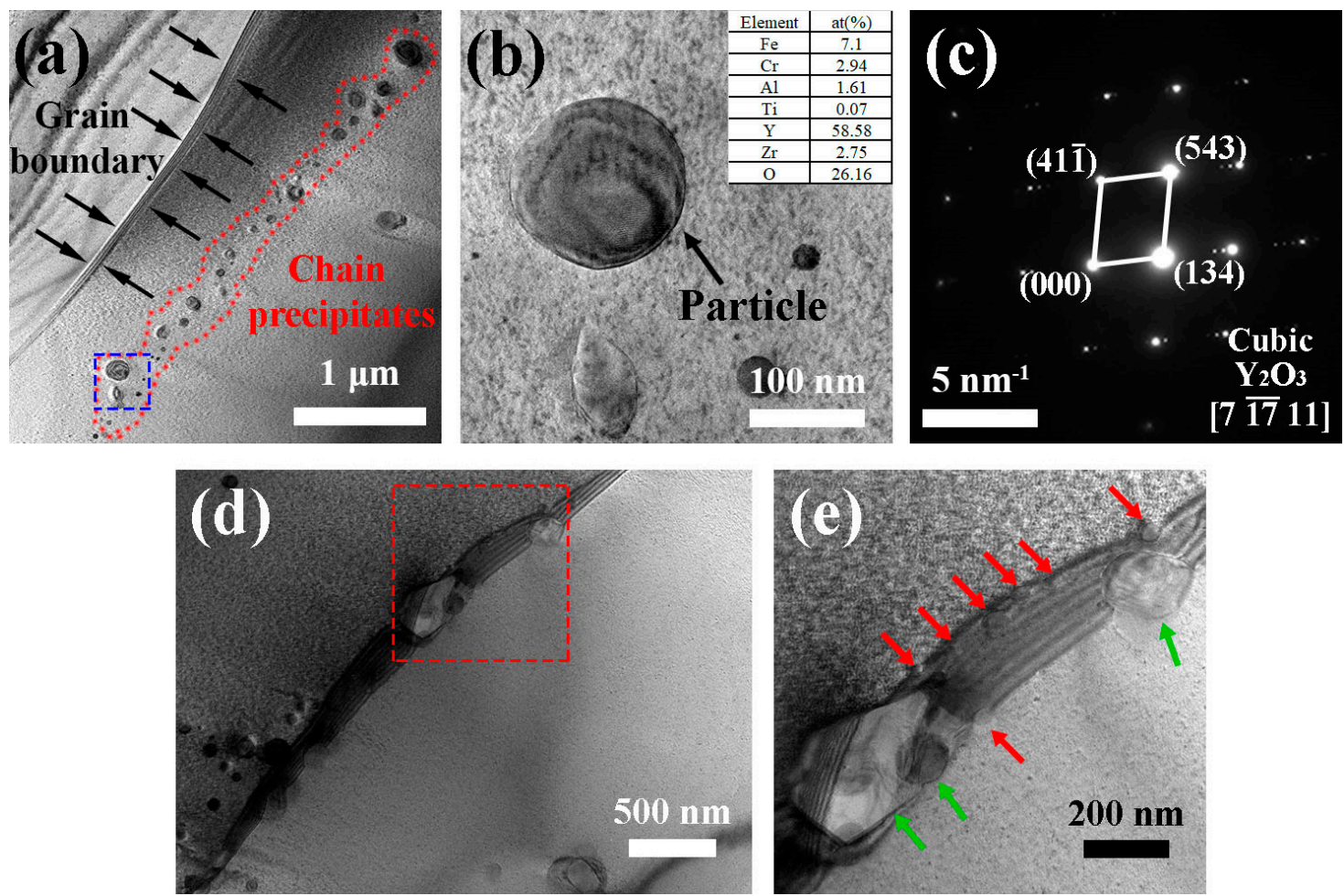

Figure 5. (a) TEM bright field image of continuous precipitates near the grain boundary in the as-HIPed alloy B; (b) high magnification of the area inside the dashed blue line in (a); (c) SAD pattern for the arrowed particle in (b); (d) TEM bright field image of the precipitates at the grain boundary; (e) high magnification of the area inside the dashed red line in (d); grain boundary precipitates of different sizes are pointed by red and green arrows. 
Continuous precipitates were found at the grain boundaries (Figure 5d). Figure 5e is a magnification of the zone in Figure $5 \mathrm{~d}$ marked by a red dotted line. The size of the precipitates in Figure 5e close to and at grain boundaries varied from 20 to $500 \mathrm{~nm}$. Furthermore, small-sized precipitates (about $20 \mathrm{~nm}$, pointed by red arrows) were distributed at grain boundaries and around large-sized precipitates (over $200 \mathrm{~nm}$, pointed by green arrows), thereby forming a stripe at grain boundaries.

\subsection{Tensile Test and Fracture Surface Analysis}

We determined the tensile strengths of both as-HIPed alloys at $25^{\circ} \mathrm{C}$. Figure 6 shows their yield strength (YS), ultimate tensile strength (UTS), and elongation (A). The average UTSs of the as-HIPed alloys A and B were $604 \mathrm{MPa}$ and $669 \mathrm{MPa}$, respectively. On the other hand, the average YS of the as-HIPed alloy A was $468 \mathrm{MPa}$ and that of the as-HIPed alloy B was $506 \mathrm{MPa}$. In addition, both samples had a brittle facture during the tensile test at $25{ }^{\circ} \mathrm{C}$. Our results indicated that the fracture elongations of the as-HIPed A and B were $7.6 \%$ and $7.2 \%$, respectively. Afterwards, the SEM was used for fractography on the tensile tested samples in order to understand the effect of the precipitates on the fracture behavior of these as-HIPed alloys.

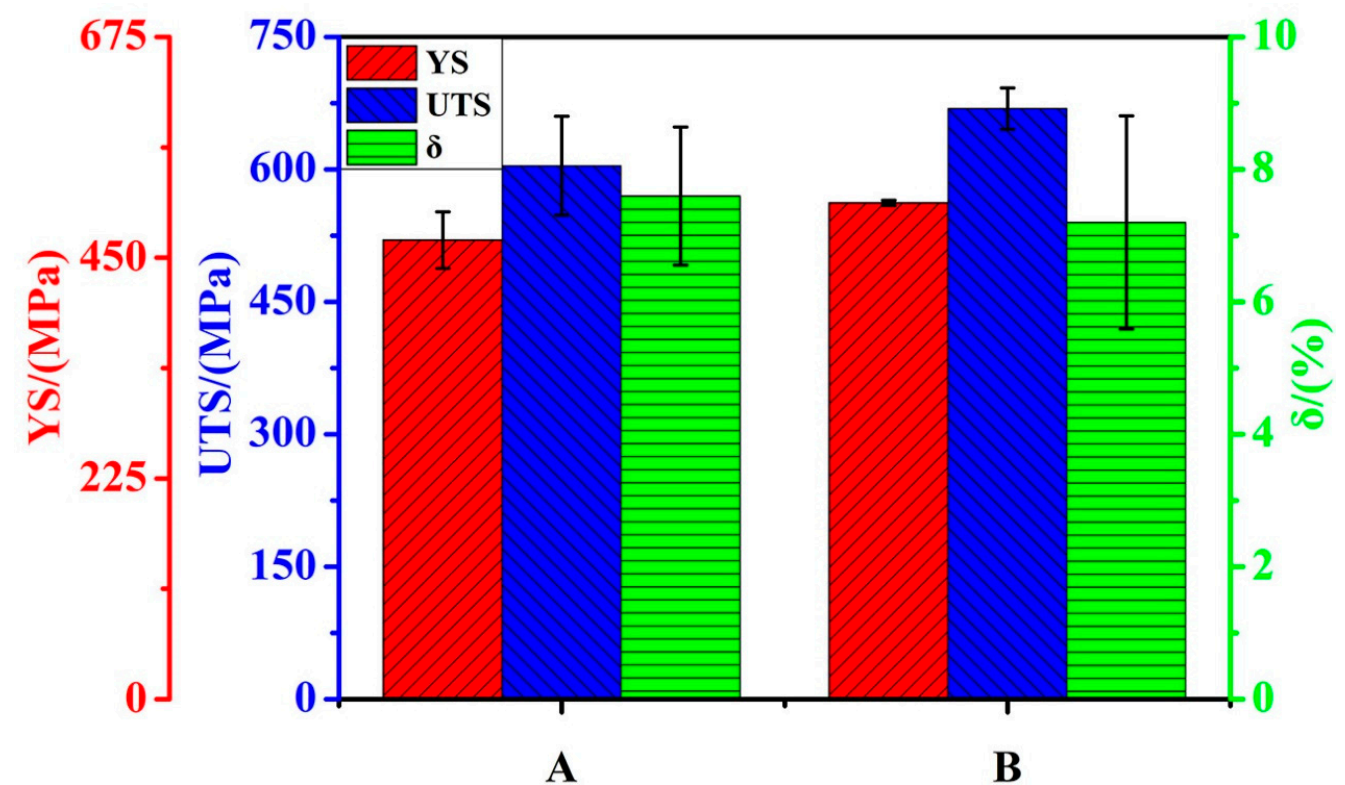

Figure 6. The ultimate tensile strength (UTS), yield strength (YS), and elongation ( $\delta$ ) for the as-HIPed alloys $\mathrm{A}$ and $\mathrm{B}$ at $25^{\circ} \mathrm{C}$.

Figure 7 shows the fractography of the as-HIPed alloy A. Results showed a brittle fracture in the as-HIPed alloy A, and the fracture surface was a cleavage fracture (Figure 7a). Furthermore, we observed a large aggregated particle (about $22 \mu \mathrm{m}$ ) at the fracture source (marked by a red dashed frame in Figure $7 \mathrm{~b}$ and a blue arrow in Figure $7 \mathrm{c}$ ) along the river pattern at the fracture surface. The magnified image of the particle and the EDS results are shown in Figure 7c. These EDS results indicated that the aggregated particle was Y-rich. In addition, there was a high $C$ content in the aggregated Y-rich oxide. The high $C$ content of the large aggregated particles may come from two sources: one is organisms deposited on the powder surfaces during the process of materials preparation; another is residual impurities, such as carbide or dust, which were introduced during the preparation and collection of the powders. The aggregated oxide particles were observed on two of the fracture surfaces of the three tested samples. Although the aggregated oxide particles are not a major issue, they are a reason for the instability of the tensile strength and should be avoided. 


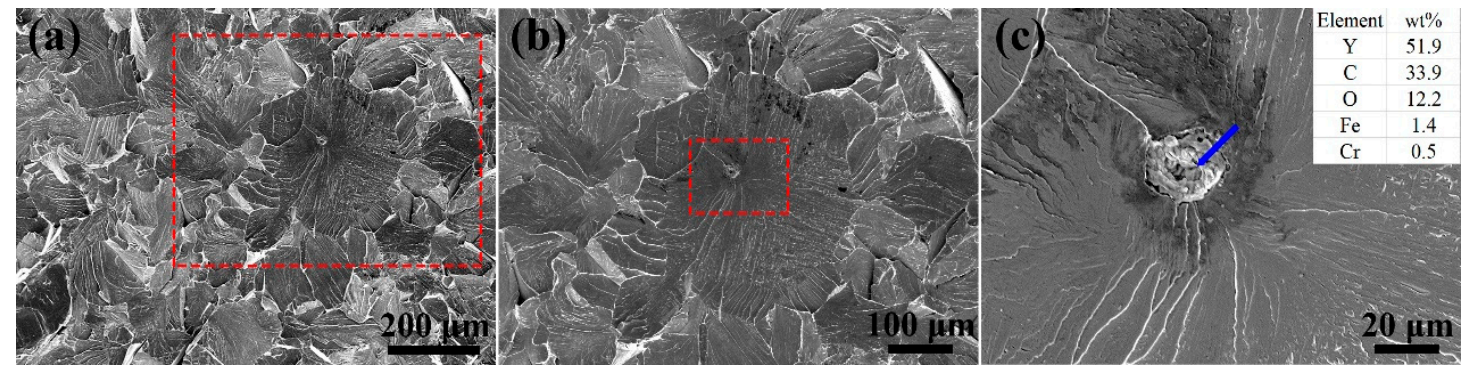

Figure 7. SEM secondary electron micrographs of the fractography for the tensile tested sample: (a) macro-morphology; $(\mathbf{b}, \mathbf{c})$ micrographs of the crack source surface of the as-HIPed alloy A at a high magnification.

Figure 8 shows the fractography of the as-HIPed alloy B. The magnified image of the area marked by a red dashed frame in Figure 8a is shown in Figure 8b. The tensile test results revealed that there was also a brittle fracture in the as-HIPed alloy B (Figure 8a). The fracture surface was mainly a cleavage fracture, with a partial area having an intergranular fracture, which is pointed by yellow arrows in Figure 8a. An intergranular fracture was observed on the fracture surfaces of all three tested samples. The EDS results indicated that there were fine and dense Y-rich precipitates on the fracture surface (Figure 8c), which were the main reason for the occurrence of a partial intergranular fracture in the as-HIPed alloy B.
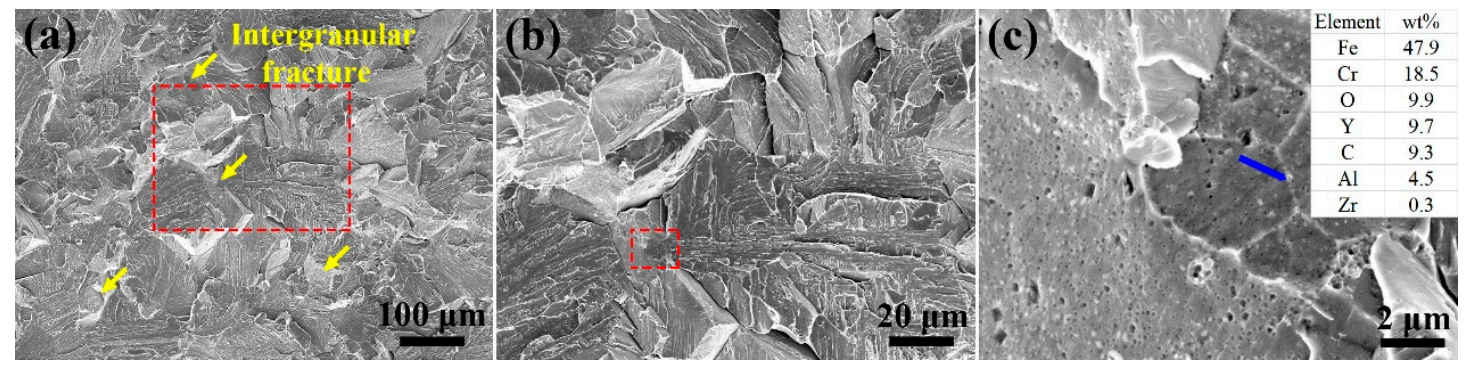

Figure 8. SEM secondary electron micrographs of the fractography for the tensile tested sample: (a) macro-morphology; $(\mathbf{b}, \mathbf{c})$ micrographs of the crack source surface of the as-HIPed alloy B at a high magnification.

\section{Discussion}

The microstructure and mechanical properties of powder metallurgy alloys are influenced by the oxygen content of powders and oxides on the powder surface [31,34,37]. During the gas atomization process, the atomized powders would inevitably react with oxygen in the environment to form metastable Fe- and Cr-oxides on the powder surface [38]. Subsequently, the metastable oxides would decompose and react with the Y element during hot isostatic pressing, which segregated at grain boundaries due to the low solid solution in the Fe-based alloy at high temperatures, thereby forming fine and stable Y-containing precipitates at and near grain boundaries [39-41], as shown in Figures 3c and 4c. During this process, the metastable $\mathrm{Fe}$ - and $\mathrm{Cr}$-oxides on the powder surface would provide a nucleation position and partial oxygen to promote the formation of stable Y-containing precipitates at and near grain boundaries.

The excellent mechanical property of ODS steels is attributed to the fine and stable dispersed oxides. Li et al. reported that the average size of nano-oxides in 16Cr ODS steel slightly increased with a percentage of $15.7 \%$ when the aging time was up to $5000 \mathrm{~h}$ at $973 \mathrm{~K}$ [21]. Increasing the oxygen content and adding $\mathrm{Y}$ and $\mathrm{Zr}$ elements can promote the formation of thermodynamically stable nano-oxides [25,42]. Our results indicated that in the as-HIPed alloy A, the fine and stable Y-rich oxides were mainly distributed at and near grain boundaries. Moreover, increasing the oxygen content from 0.04 to $0.16 \mathrm{wt} \%$ led to the precipitation of a large amount of fine Y-rich oxides within grains in the as-HIPed alloy $\mathrm{B}$, and formation of chain oxides near and at grain boundaries. Even the small spherical $\mathrm{Y}_{2} \mathrm{O}_{3}$ 
oxides grew into stripe oxides at grain boundaries. In addition, $\mathrm{Y}$ could react with $\mathrm{O}$ and $\mathrm{Ti} / \mathrm{Al} / \mathrm{Zr}$ to form more stable ternary $\mathrm{Y}$ - $\mathrm{Ti} / \mathrm{Al} / \mathrm{Zr}-\mathrm{O}$ oxides $\left(\mathrm{Y}_{2} \mathrm{Ti}_{2} \mathrm{O}_{7}, \mathrm{Y}_{2} \mathrm{TiO}_{5}, \mathrm{Y}_{3} \mathrm{Al}_{5} \mathrm{O}_{12}\right.$, $\left.\mathrm{Y}_{4} \mathrm{Al}_{2} \mathrm{O}_{9}, \mathrm{YAlO}_{3}, \mathrm{Y}_{4} \mathrm{Zr}_{3} \mathrm{O}_{12}\right)$ [8,26-29]. The formation of these ternary $\mathrm{Y}$-containing oxides needs to consume more oxygen compared to the formation of $\mathrm{Y}_{2} \mathrm{O}_{3}$.

The dispersed precipitates at grain boundaries and in the matrix are the main reasons for the high tensile and creep strength of ODS steels $[12,20]$. With a precipitate density increase and a size decrease, the yield strength and tensile strength of ODS steels increased, but the elongation decreased and a brittle fracture occurred [33]. The fine and dispersed oxides improved the tensile strength of alloys by pinning dislocations and blocking grain boundary movement [5]. The results showed that increasing the oxygen content increased the ultimate tensile strength and yield strength of the as-HIPed alloy B by $10.7 \%$ and $8.1 \%$, respectively, compared to the as-HIPed alloy A [43]. A brittle fracture occurred in both as-HIPed alloys A and B, and the mean elongations of the two alloys were $7.6 \%$ and $7.2 \%$, respectively. The brittle fracture of both alloys could be attributed to the aggregated large-sized Y-rich particle and the stripe/chain precipitates near and at grain boundaries, which could decrease the strength of grain boundaries. They easily become crack initiations due to stress concentration, thereby causing a brittle fracture of alloys during a tensile test [44].

Notably, compared to the FeCrAl-ODS steels prepared by MA following HIP with grain sizes of less than $10 \mu \mathrm{m}[45,46]$, the strength of the alloys in this study was low. There are three factors responsible for the low strength of as-HIPed alloys: large grain size, numerous impure particles in the matrix, and low density of the precipitates within grains. The grain size of about $100 \mu \mathrm{m}$ is larger than in other ODS alloys prepared by mechanical alloying [25,28]. The larger grain size is detrimental to the toughness of the alloys. Refining the grain size can improve the toughness and strength of an alloy. Lowering HIP temperature and shortening HIP time can prevent the grain growth during the HIP process [34]. Optimizing the composition of powders, reducing the as-atomized powder size, and avoiding the impurity particles in powders can effectively improve the strength and ductility of an alloy [32,47]. Furthermore, the grain size can be refined by thermomechanical processing after HIP $[28,43]$. The large and continuous precipitates in the alloy can also be refined and dispersed during the thermomechanical process, which may be an effective method for improving the strength and toughness of as-HIPed alloys.

\section{Conclusions}

In this study, we produced two 22Cr-5Al ODS steels with different oxygen contents through the GARS route and HIP. We then conducted microstructure characterization and tensile tests at room temperature in order to investigate the effect of oxygen content on the microstructure and tensile strength of the as-HIPed 22Cr-5Al ODS steels. The following conclusions were drawn:

1. The precipitates in the as-HIPed alloys mainly were Y-rich oxides. An increase in the oxygen content from 0.04 to $0.16 \mathrm{wt} \%$ led to an increase in the number and density of precipitates in the as-HIPed alloy. Meanwhile, the Y-rich precipitates segregated at and near grain boundaries and formed large-sized stripe/chain precipitates.

2. With the increase in oxygen content from 0.04 to $0.16 \mathrm{wt} \%$, the ultimate tensile strength of the as-HIPed alloy increased from 604 to $669 \mathrm{MPa}$, and the yield strength increased from 468 to $506 \mathrm{MPa}$. However, a brittle fracture occurred in both as-HIPed alloys, which could be attributed to the segregation of large-sized oxides and the stripe/chain Y-rich precipitates at and near grain boundaries.

Author Contributions: Y.Z. (Yukun Zhang): Data curation, Investigation, Writing-Original draft preparation, Writing-review and editing, Visualization. Y.Y.: Conceptualization, Investigation, Funding acquisition, Writing-Original draft preparation. Y.Z. (Yazhong Zhai): Data curation, Investigation, Writing-Original draft preparation. W.Q.: Investigation, Resources, Writing-Original draft preparation. H.C.: Conceptualization, Resources, Writing-review and editing. T.W.: Concep- 
tualization, Writing-review and editing. R.C.: Conceptualization, Writing-review and editing, Funding acquisition. All authors have read and agreed to the published version of the manuscript.

Funding: This work was supported by the National Natural Science Foundation of China (51961024, 52071170, 51761027).

Institutional Review Board Statement: Not applicable.

Informed Consent Statement: Not applicable.

Data Availability Statement: The data presented in this study are available on request from the corresponding author.

Conflicts of Interest: The authors declare no conflict of interest.

\section{References}

1. Lo, K.H.; Shek, C.H.; Lai, J.K.L. Recent developments in stainless steels. Mater. Sci. Eng. R Rep. 2009, 65, 39-104. [CrossRef]

2. Odette, G.R.; Alinger, M.J.; Wirth, B.D. Recent Developments in Irradiation-Resistant Steels. Annu. Rev. Mater. Sci. 2008, 38, 471-503. [CrossRef]

3. Eiselt, C.C.; Schendzielorz, H.; Seubert, A.; Hary, B.; de Carlan, Y.; Diano, P.; Perrin, B.; Cedat, D. ODS-materials for high temperature applications in advanced nuclear systems. Nucl. Mater. Energy 2016, 9, 22-28. [CrossRef]

4. Zinkle, S.J.; Was, G.S. Materials challenges in nuclear energy. Acta Mater. 2013, 61, 735-758. [CrossRef]

5. Ijiri, Y.; Oono, N.; Ukai, S.; Ohtsuka, S.; Kaito, T.; Matsukawa, Y. Oxide particle-dislocation interaction in 9Cr-ODS steel. Nucl. Mater. Energy 2016, 9, 378-382. [CrossRef]

6. Oono, N.; Tang, Q.X.; Ukai, S. Oxide particle refinement in Ni-based ODS alloy. Mater. Sci. Eng. A 2016, 649, 250-253. [CrossRef]

7. Song, M.; Sun, C.; Jang, J.; Han, C.H.; Kim, T.K.; Hartwig, K.T.; Zhang, X. Microstructure refinement and strengthening mechanisms of a 12Cr ODS steel processed by equal channel angular extrusion. J. Alloys Compd. 2013, 577, 247-256. [CrossRef]

8. Gao, R.; Zhang, T.; Wang, X.P.; Fang, Q.F.; Liu, C.S. Effect of zirconium addition on the microstructure and mechanical properties of ODS ferritic steels containing aluminum. J. Nucl. Mater. 2014, 444, 462-468. [CrossRef]

9. Xu, H.; Lu, Z.; Wang, D.; Liu, C. Effect of zirconium addition on the microstructure and mechanical properties of 15Cr-ODS ferritic Steels consolidated by hot isostatic pressing. Fusion Eng. Des. 2017, 114, 33-39. [CrossRef]

10. Darling, K.A.; Rajagopalan, M.; Komarasamy, M.; Bhatia, M.A.; Hornbuckle, B.C.; Mishra, R.S.; Solanki, K.N. Extreme creep resistance in a microstructurally stable nanocrystalline alloy. Nature 2016, 537, 378-381. [CrossRef]

11. Yano, Y.; Sekio, Y.; Tanno, T.; Kato, S.; Inoue, T.; Oka, H.; Ohtsuka, S.; Furukawa, T.; Uwaba, T.; Kaito, T.; et al. Ultra-high temperature creep rupture and transient burst strength of ODS steel claddings. J. Nucl. Mater. 2019, 516, 347-353. [CrossRef]

12. Hayashi, T.; Sarosi, P.M.; Schneibel, J.H.; Mills, M.J. Creep response and deformation processes in nanocluster-strengthened ferritic steels. Acta Mater. 2008, 56, 1407-1416. [CrossRef]

13. Jaumier, T.; Vincent, S.; Vincent, L.; Desmorat, R. Creep and damage anisotropies of $9 \% \mathrm{Cr}$ and $14 \% \mathrm{Cr}$ ODS steel cladding. J. Nucl. Mater. 2019, 518, 274-286. [CrossRef]

14. Hilger, I.; Boulnat, X.; Hoffmann, J.; Testani, C.; Bergner, F.; De Carlan, Y.; Ferraro, F.; Ulbricht, A. Fabrication and characterization of oxide dispersion strengthened (ODS) $14 \mathrm{Cr}$ steels consolidated by means of hot isostatic pressing, hot extrusion and spark plasma sintering. J. Nucl. Mater. 2016, 472, 206-214. [CrossRef]

15. Oksiuta, Z.; Lewandowska, M.; Kurzydlowski, K.; Baluc, N. Reduced activation ODS ferritic steel - recent development in high speed hot extrusion processing. Phys. Status Solidi (A) 2010, 207, 1128-1131. [CrossRef]

16. Karak, S.K.; Majumdar, J.D.; Witczak, Z.; Lojkowski, W.; Manna, I. Microstructure and mechanical properties of nano-Y2O3 dispersed ferritic alloys synthesized by mechanical alloying and consolidated by hydrostatic extrusion. Mater. Sci. Eng. A 2013, 580, 231-241. [CrossRef]

17. Dash, M.K.; Mythili, R.; Ravi, R.; Sakthivel, T.; Dasgupta, A.; Saroja, S.; Bakshi, S.R. Microstructure and mechanical properties of oxide dispersion strengthened $18 \mathrm{Cr}$-ferritic steel consolidated by spark plasma sintering. Mater. Sci. Eng. A 2018, 736, 137-147. [CrossRef]

18. Shi, Y.; Lu, Z.; Yu, L.; Xie, R.; Ren, Y.; Yang, G. Microstructure and tensile properties of Zr-containing ODS-FeCrAl alloy fabricated by laser additive manufacturing. Mater. Sci. Eng. A 2020, 774, 138937. [CrossRef]

19. Kürnsteiner, P.; Wilms, M.B.; Weisheit, A.; Barriobero-Vila, P.; Gault, B.; Jägle, E.A.; Raabe, D. In-process Precipitation During Laser Additive Manufacturing Investigated by Atom Probe Tomography. Microsc. Microanal. 2017, 23, 694-695. [CrossRef]

20. Liu, T.; Wang, L.; Wang, C.; Shen, H.; Zhang, H. Feasibility of using Y2Ti2O7 nanoparticles to fabricate high strength oxide dispersion strengthened Fe-Cr-Al steels. Mater. Des. 2015, 88, 862-870. [CrossRef]

21. Li, S.F.; Zhou, Z.J.; Wang, P.H.; Sun, H.Y.; Wang, M.; Zhang, G.M. Long-term thermal-aging stability of a 16Cr-oxide dispersion strengthened ferritic steel at 973 K. Mater. Des. 2016, 90, 318-329. [CrossRef]

22. Ma, S.; Li, A.; Zhou, S.; Yang, Y.; Wang, S.; Liu, M. Microstructure and mechanical properties of nickel strengthened by Y2O3 through rock-milling and spark plasma sintering. J. Alloys Compd. 2018, 750, 911-916. [CrossRef] 
23. Zhou, X.; Li, C.; Yu, L.; Li, H.; Liu, Y. Effects of Ti addition on microstructure and mechanical property of spark-plasma-sintered transformable 9Cr-ODS steels. Fusion Eng. Des. 2018, 135, 88-94. [CrossRef]

24. Zhang, L.; Yu, L.; Liu, Y.; Liu, C.; Li, H.; Wu, J. Influence of Zr addition on the microstructures and mechanical properties of $14 \mathrm{Cr}$ ODS steels. Mater. Sci. Eng. A 2017, 695, 66-73. [CrossRef]

25. Xu, H.; Lu, Z.; Wang, D.; Zhang, Z.; Han, Y.; Liu, C. Structure and composition of oxides in FeCrAl ODS alloy with Zr addition. Mater. Sci. Technol. 2017, 33, 1790-1795. [CrossRef]

26. Xia, Y.P.; Wang, X.P.; Zhuang, Z.; Sun, Q.X.; Zhang, T.; Fang, Q.F.; Hao, T.; Liu, C.S. Microstructure and oxidation properties of 16Cr-5Al-ODS steel prepared by sol-gel and spark plasma sintering methods. J. Nucl. Mater. 2013, 432, 198-204. [CrossRef]

27. Seol, J.B.; Haley, D.; Hoelzer, D.T.; Kim, J.H. Influences of interstitial and extrusion temperature on grain boundary segregation, $\mathrm{Y}-\mathrm{Ti}-\mathrm{O}$ nanofeatures, and mechanical properties of ferritic steels. Acta Mater. 2018, 153, 71-85. [CrossRef]

28. Alinger, M.J.; Odette, G.R.; Hoelzer, D.T. On the role of alloy composition and processing parameters in nanocluster formation and dispersion strengthening in nanostuctured ferritic alloys. Acta Mater. 2009, 57, 392-406. [CrossRef]

29. Boulnat, X.; Sallez, N.; Dadé, M.; Borbély, A.; Béchade, J.L.; de Carlan, Y.; Malaplate, J.; Bréchet, Y.; de Geuser, F.; Deschamps, A.; et al. Influence of oxide volume fraction on abnormal growth of nanostructured ferritic steels during non-isothermal treatments: An in situ study. Acta Mater. 2015, 97, 124-130. [CrossRef]

30. Zhong, S.Y.; Ribis, J.; Lochet, N.; de Carlan, Y.; Klosek, V.; Mathon, M.H. Influence of nano-particle coherency degree on the coarsening resistivity of the nano-oxide particles of Fe-14Cr-1W ODS alloys. J. Nucl. Mater. 2014, 455, 618-623. [CrossRef]

31. Lin, J.B.Q. Review and Analysis of Powder Prior Boundary (PPB) Formation in Powder Metallurgy Processes for Nickel-based Super Alloys. J. Powder Metall. Min. 2015, 4, 2. [CrossRef]

32. Klueh, R.L.; Shingledecker, J.P.; Swindeman, R.W.; Hoelzer, D.T. Oxide dispersion-strengthened steels: A comparison of some commercial and experimental alloys. J. Nucl. Mater. 2005, 341, 103-114. [CrossRef]

33. Kumar, D.; Prakash, U.; Dabhade, V.V.; Laha, K.; Sakthivel, T. High yttria ferritic ODS steels through powder forging. J. Nucl. Mater. 2017, 488, 75-82. [CrossRef]

34. Ordás, N.; Gil, E.; Cintins, A.; de Castro, V.; Leguey, T.; Iturriza, I.; Purans, J.; Anspoks, A.; Kuzmin, A.; Kalinko, A. The role of yttrium and titanium during the development of ODS ferritic steels obtained through the STARS route: TEM and XAS study. J. Nucl. Mater. 2018, 504, 8-22. [CrossRef]

35. Rieken, J.R.; Anderson, I.E.; Kramer, M.J.; Odette, G.R.; Stergar, E.; Haney, E. Reactive gas atomization processing for Fe-based ODS alloys. J. Nucl. Mater. 2012, 428, 65-75. [CrossRef]

36. Nagini, M.; Vijay, R.; Rajulapati, K.V.; Reddy, A.V.; Sundararajan, G. Microstructure-mechanical property correlation in oxide dispersion strengthened 18Cr ferritic steel. Mater. Sci. Eng. A 2017, 708, 451-459. [CrossRef]

37. Warren, R.; Ingesten, N.G.; Winberg, L.; Rönnhult, T. Particle Surfaces and Prior Particle Boundaries in Hf Modified PM Astroloy. Powder Metall. 2013, 27, 141-146. [CrossRef]

38. Karlsson, H.; Nyborg, L.; Berg, S. Surface chemical analysis of prealloyed water atomised steel powder. Powder Metall. 2005, 48, 51-58. [CrossRef]

39. Cintins, A.; Anspoks, A.; Purans, J.; Kuzmin, A.; Timoshenko, J.; Vladimirov, P.; Gräning, T.; Hoffmann, J. ODS steel raw material local structure analysis using X-ray absorption spectroscopy. IOP Conf. Ser. Sci. Eng. 2015, 77, 012029. [CrossRef]

40. Zhang, B.W.; Liu, G.; Han, K. The Fe-Y (iron-yttrium) system. J. Phase Equilibria 1992, 13, 304-308. [CrossRef]

41. Gao, X.; Ren, H.; Wang, H.; Chen, S. Activity coefficient and solubility of yttrium in Fe-Y dilute solid solution. J. Rare Earths 2016, 34, 1168-1172. [CrossRef]

42. Kotan, H.; Darling, K.A.; Scattergood, R.O.; Koch, C.C. Influence of Zr and nano-Y2O3 additions on thermal stability and improved hardness in mechanically alloyed Fe base ferritic alloys. J. Alloys Compd. 2014, 615, 1013-1018. [CrossRef]

43. Dadé, M.; Malaplate, J.; Garnier, J.; De Geuser, F.; Barcelo, F.; Wident, P.; Deschamps, A. Influence of microstructural parameters on the mechanical properties of oxide dispersion strengthened Fe-14Cr steels. Acta Mater. 2017, 127, 165-177. [CrossRef]

44. Shi, S.; Zhu, L.; Zhang, H.; Sun, Z. Segregation effects of Y, Ti, Cr and Si on the intergranular fracture of niobium. J. Alloys Compd. 2017, 711, 637-642. [CrossRef]

45. Li, S.; Zhou, Z.; Li, M.; Wang, M.; Zhang, G. Microstructure characterization and tensile properties of $18 \mathrm{Cr}-4 \mathrm{Al}$-oxide dispersion strengthened ferritic steel. J. Alloys Compd. 2015, 648, 39-45. [CrossRef]

46. Zhao, Q.; Yu, L.; Liu, Y.; Huang, Y.; Ma, Z.; Li, H.; Wu, J. Microstructure and tensile properties of a 14Cr ODS ferritic steel. Mater. Sci. Eng. A 2017, 100, 347-350. [CrossRef]

47. Sun, Z.; Bei, H.; Yamamoto, Y. Microstructural control of FeCrAl alloys using Mo and Nb additions. Mater. Charact. 2017, 132, 126-131. [CrossRef] 